\title{
Observations on Some Transonic Wind Tunnel Test Results of a Standard Model with a T-Tail
}

\author{
Dijana Damljanović ${ }^{1)}$ \\ Đorđe Vuković ${ }^{1)}$ \\ Aleksandar Vitic ${ }^{1)}$ \\ Jovan Isakovic ${ }^{2)}$ \\ Goran Ocokoljić ${ }^{1)}$
}

\begin{abstract}
As a part of a periodic health monitoring of the wind tunnel structure, instrumentation and flow quality, a series of tests of an AGARD-C calibration model was performed in the $1.5 \mathrm{~m} \mathrm{T-38}$ trisonic wind tunnel of the Military Technical Institute (VTI) in Belgrade. The tests comprised measurements of the forces and moments in the transonic Mach number range with the purpose of comparing the model's obtained aerodynamic characteristics with those from other wind tunnel laboratories, in accordance with an adopted procedure for standard models testing. Inter-facility correlations were based on test results of physically the same model in the $\mathbf{5 f t}$ trisonic wind tunnel of the National Research Council (later operated as National Aeronautical Establishment) of Canada, in the $\mathbf{1 . 2} \mathrm{m}$ trisonic wind tunnel of the Romanian National Institute for Scientific and Technical Creation and in the T-38 wind tunnel during the commissioning period. Analysis of correlated test results confirmed a good flow quality in the T-38 test section, good condition of wind tunnel structure and instrumentation, and the correctness of the data reduction algorithm. Small differences were observed in the pitching moment coefficient data obtained in the 'normal' and 'inverted' model configurations, and it has preliminary been concluded that the effect may have been caused by a slight asymmetry of flow in the rear part of the wind tunnel test section, the AGARD-C model being known for the high sensitivity of the pitching moment to local conditions.
\end{abstract}

Key words: wind tunnel, transonic flow, aerodynamic model, aerodynamic characteristics, aerodynamic forces, aerodynamic moment.

\section{Introduction}

$\mathrm{T}$ HE Military Technical Institute (VTI) in Belgrade has established a procedure for wind-tunnel data quality assurance, primarily based on periodic testing of the AGARDB standard model [1]. The procedure comprises wind-tunnel testing, maintenance of a database of the standard test results and a statistical control on the test data, [2-4]. Considerations and directives recommended in the procedure have now been applied and implemented in testing of the AGARD standard model C with a T-tail. The intention of the research was to start the statistical control on the database of wind tunnel results for this model. The obtained and analyzed results will serve to ascertain the stability of the measurement process and help in the future tests of similar configurations.

AGARD-C model configuration differs from the betterknown AGARD-B configuration by the addition of a rearbody segment with a T-tail. The longer body of the AGARD model $\mathrm{C}$ and the existence of the T-tail make it easier to detect (from anomalies in the wind tunnel test results) if the shock waves reflected from the walls of the wind tunnel test section are passing too close to the rear end of the model. The existence of the tail also makes this model more sensitive than AGARD-B to flow curvature in the wind tunnel test section.
The configuration was originally designed for calibration of transonic wind tunnels [5-7] and primarily used in them. Unfortunately, the database of published test results is somewhat smaller than the one for the AGARD-B model. Beside the review data available in [7] comprising results from AEDC, Boeing, ONERA and NLR, which, unfortunately, is of very poor legibility, available test results include [8] those from the Canadian $5 \mathrm{ft}$ trisonic blowdown wind tunnel of the National Research Council (NRC), later operated as National Aeronautical Establishment (NAE) [9], those from the Romanian $1.2 \mathrm{~m}$ trisonic blowdown wind tunnel $[10,11]$ of the National Institute for Scientific and Technical Creation (INCREST, now INCAS - National Institute for Aerospace Research) and tests made during the commissioning of the $1.5 \mathrm{~m} \mathrm{~T}-38$ wind tunnel of VTI [12]. The intention of the authors is to extend the amount of data and make it available to the community.

\section{Standard model with a T-tail}

AGARD-C standard model, a derivative of the well-known standard AGARD-B model, is an ogive-cylinder with a delta wing and a horizontal and a vertical tail in the T-tail configuration, Fig.1.

\footnotetext{
1) Military Technical Institute (VTI), Ratka Resanovića 1, 11132 Belgrade, SERBIA

2) College of Applied Engineering Studies, Tehnikum Taurunum, Nade Dimić 4, 11080 Zemun, SERBIA

Correspondence to: Dijana Damljanović; e-mail: didamlj@gmail.com
} 


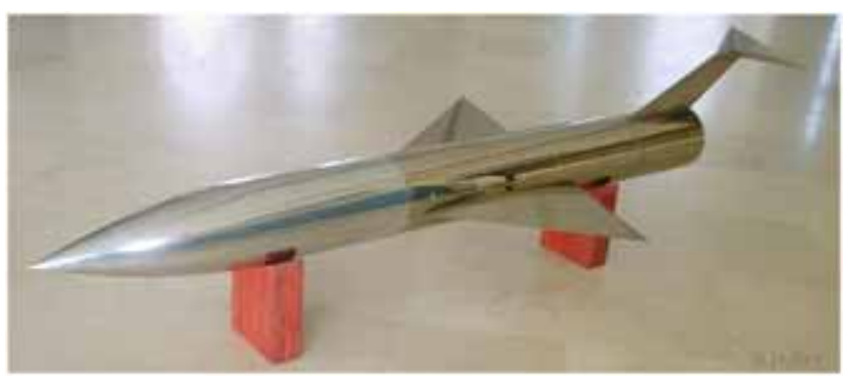

Figure 1. AGARD-C model with a body diameter of $115.8 \mathrm{~mm}$

At the AGARD Wind Tunnel and Model Testing Panel meeting in Paris, France, in 1954, it was agreed [7] to add a third model configuration to the family of AGARD standard calibration models, by extending the body of the AGARD-B by 1.5 diameters and by adding a T-tail.

The horizontal tail has an area equal to $1 / 6$ of the wing area. Sections of the vertical and horizontal tail are circular and the profiles are defined identically to the profile of the wing. At the front of the 1.5D body extension, the geometry of the AGARD-C model is identical to that of the AGARD-B: an $8.5 \mathrm{D}$ long solid body of revolution consisting of the $5.5 \mathrm{D}$ long cylindrical segment and a nose with the length of 3D.

Also, the position of the moments reduction point (the aerodynamic centre) is the same as on AGARD-B. All its dimensions are given in terms of the body diameter $\mathrm{D}$ so that the model can be produced in any scale, which makes it appropriate for a particular wind tunnel, Fig. 2 .

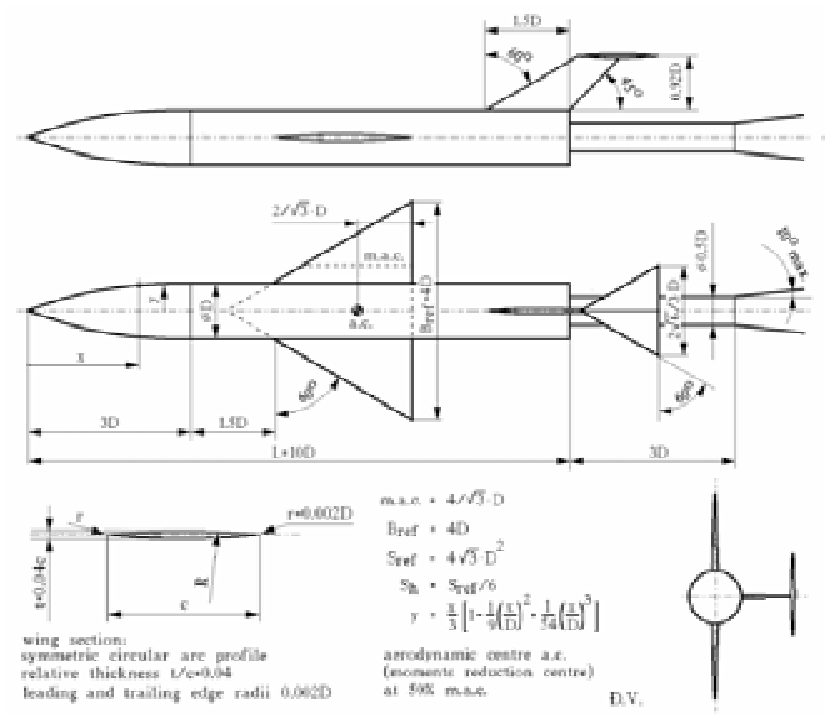

Figure 2. A drawing defining the geometry of the AGARD-C standard model and its sting fixture

The support sting for the AGARD-C model is identical to the sting for the AGARD-B model, having a length of $3 \mathrm{D}$ aft of model base and a diameter of $0.5 \mathrm{D}$. In order to reduce cost and produce more versatile wind tunnel models, actual designs of AGARD-B and AGARD-C are sometimes realized as an AGARD-B configuration to which a body segment with the T-tail can be attached at the rear end to form the AGARD$\mathrm{C}$ configuration.

The AGARD-C wind tunnel calibration model, used in T-38, was supplied by Boeing. Model size (of $115.8 \mathrm{~mm}$ dia.) was chosen with respect to the tunnel's test section size. Model had been used in previous T-38 wind tunnel calibrations and tests in other wind tunnels. There is also a database which allows comparison with the obtained results [12].

\section{Test facility}

The T-38 test facility at the Military Technical Institute (VTI) in Belgrade is a blowdown-type pressurized wind tunnel [13] with a $1.5 \mathrm{~m} \times 1.5 \mathrm{~m}$ square test section, Fig.3. For subsonic and supersonic tests, the test section is with solid walls, while for transonic tests, a section with porous walls is inserted in the configuration. The porosity of walls can be varied between $1.5 \%$ and $8 \%$, depending on Mach number, in order to achieve the best flow quality.

Mach number in the range 0.2 to 4.0 can be achieved in the test section, with Reynolds numbers up to 110 million per metre. In the subsonic configuration, Mach number is set by sidewall flaps in the tunnel diffuser. In the supersonic configuration, Mach number is set by the flexible nozzle contour, while in transonic configuration, Mach number is both set by sidewall flaps and the flexible nozzle, and actively regulated by blow-off system. Mach number can be set and regulated to within $0.5 \%$ of the nominal value.

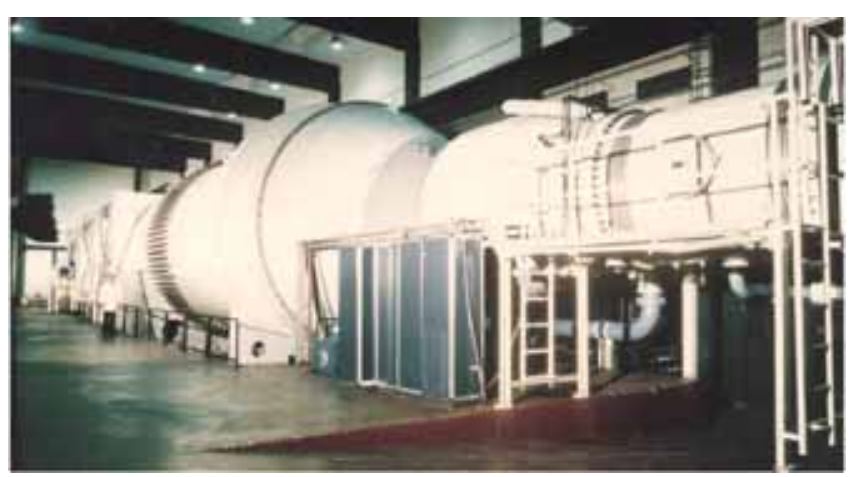

Figure 3. The T-38 test facility in VTI, Belgrade

Stagnation pressure in the test section can be maintained between 1.1 bar and 15 bar, depending on Mach number, and regulated to $0.3 \%$ of nominal value. Run times are in the range $6 \mathrm{~s}$ to $60 \mathrm{~s}$, depending on Mach number and stagnation pressure.

Model is supported in the test section by a tail sting mounted on a pitch-and-roll mechanism by which desired aerodynamic angles can be achieved, Fig.4. The facility supports both step-by-step and continuous (sweep) model movement during measurements. Positioning accuracy is $0.05^{\circ}$ in both pitch and roll.

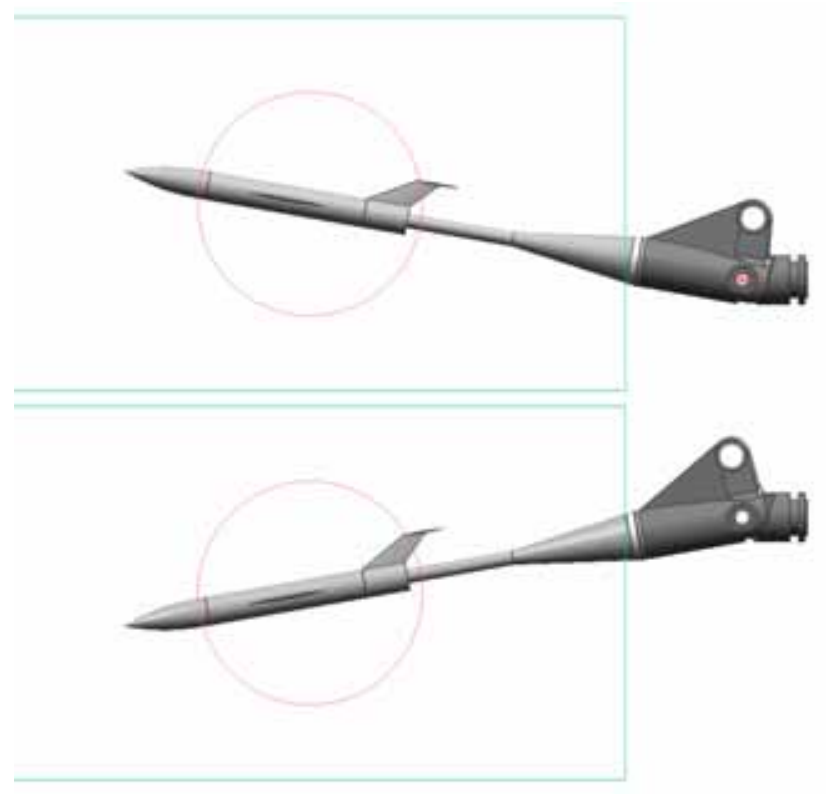

Figure 4. Pitch-and-roll model support mechanism 


\section{Results and discussion}

VTI is one of the laboratories that have adopted the practice [1] of periodic testing of a standard model every couple of years in order to provide a continued confidence in the reliability of measurements in their wind tunnels.

The adopted procedure for determining the overall T-38 wind-tunnel data quality and verification in the standard testing [1] includes a number of steps, but here, only two points are taken into the consideration: (1) the inter-facility correlations and (2) the test section symmetry correlations. Comparable test results are presented in the wind axes system in the form of graphs, showing the drag force coefficient, the lift force coefficient, the pitching moment coefficient and the base pressure coefficient as function of the angle of attack in the wind axes system. Test results are given for the model aerodynamic center, Fig.2. Model reference length is the mean aerodynamic chord.

\section{Sets of VTI test results}

A small set of early AGARD model C test data obtained during the commissioning of the T-38 wind tunnel existed in the VTI database, as the model B is more often used for wind tunnel calibration and verification, $[1,14]$. Tests had been performed at the transonic Mach numbers from 0.7 to 1.05 at angles of attack from $-2^{\circ}$ to $+13^{\circ}$ traversed in a continuous-movement mode.

An additional test campaign with this model in the T-38 wind tunnel was executed later, comprising measurements at Mach numbers from 0.7 to 1.15 . The angle of attack range was from $-4^{\circ}$ to $+10^{\circ}$ traversed in a continuous-movement mode.

\section{Inter-facility correlation}

The test data were analyzed based on correlations with the data from other experimental aerodynamics laboratories. The reference sets of data were results [8] from the Canadian $\mathrm{NRC} / \mathrm{NAE} 5 \mathrm{ft}$ trisonic wind tunnel and results [11] from the Romanian $1.2 \mathrm{~m} \times 1.2 \mathrm{~m}$ INCREST trisonic wind tunnel facility. The earlier sets of the T-38 wind-tunnel test data are also correlated [12]. All results are from the tests with the $115.8 \mathrm{~mm}$ dia. model.

A good agreement of the correlated test results confirms a high quality of air flow in the T-38 test section, good condition of the wind tunnel instrumentation and the correctness of the data reduction algorithm, Figures 5-8.

The large deviation of the pitching moment coefficient obtained in the INCREST wind tunnel is obviously a result of the reduction of the moments to a reference point different from that used in other tests. Unfortunately, the location of the reference point used in INCREST tests is not known, so the data could not be recomputed for the proper reference point.

Relatively large scatter of the base pressure coefficients in the correlations (Figure8) can probably be explained by the fact that absolute pressure transducers of the high range and, therefore, lower absolute accuracy, were used for the base pressure measurement in the NRC/NAE and in early VTI tests, while the newer VTI tests were performed using a differential pressure transducer of a lower range and higher accuracy. The method of base-pressure measurement in the INCREST wind tunnel is not known.

It should also be noted that, because of the smaller size of the INCREST wind tunnel relative to NCR and VTI wind tunnels $(1.2 \mathrm{~m}$ vs. $1.5 \mathrm{~m})$, the blockage of the AGARD-C model in tests [11] was higher than in VTI and NAE tests, which may have affected the results, including the measurement of the base pressure.

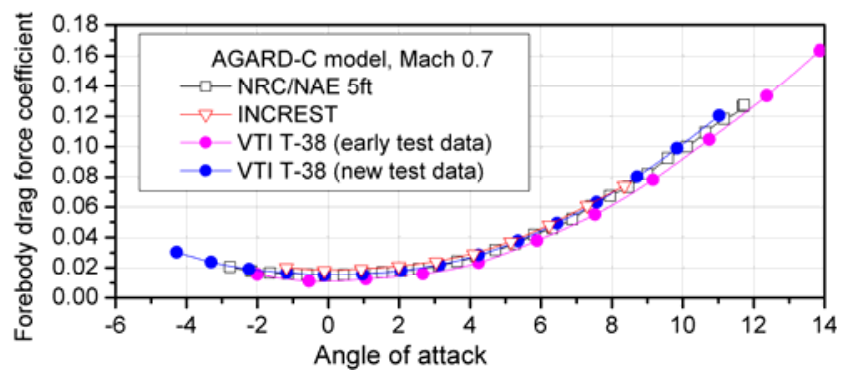

Figure 5. Inter-facility correlation in the drag force measurement

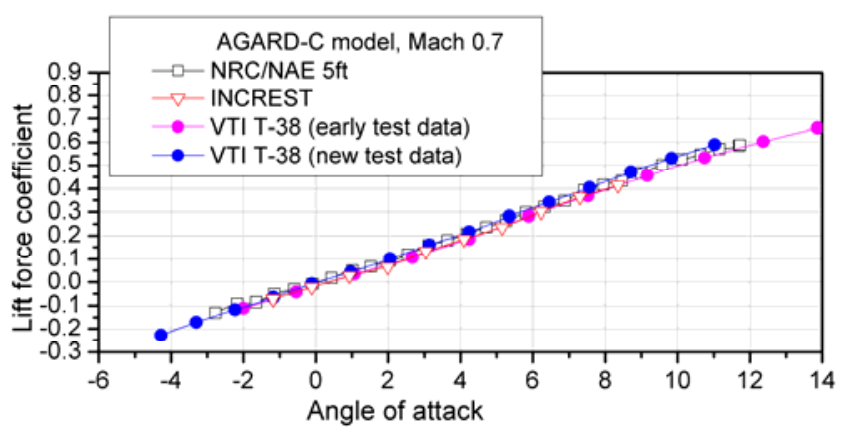

Figure 6. Inter-facility correlation in the lift force measurement

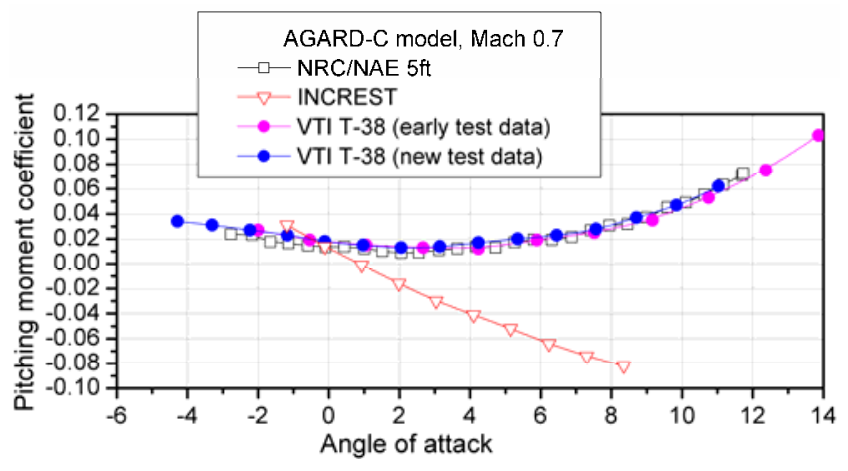

Figure 7. Inter-facility correlation in the pitching moment measurement

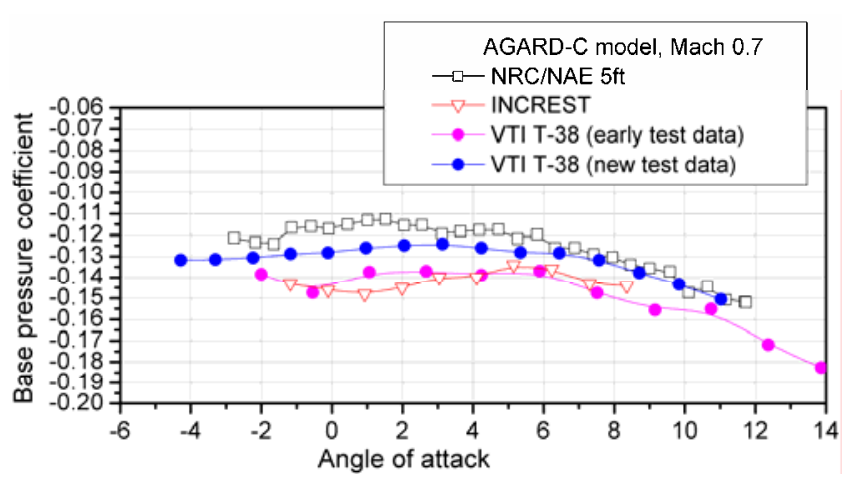

Figure 8. Inter-facility correlation in the base pressure measurement

\section{Correlation from the point of symmetry}

The test data were analyzed from the point of test section symmetry, more exactly, test results were checked from runs with model both in upright and inverted position. 


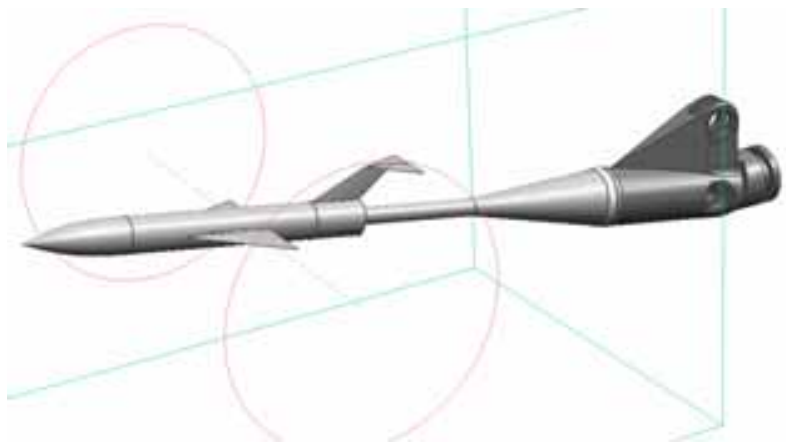

Figure 9. CAD rendering of the $115.8 \mathrm{~mm}$ dia. AGARD-C model, upright configuration, $\mathrm{T}-38$ test section, $+10^{\circ}$ angle of attack

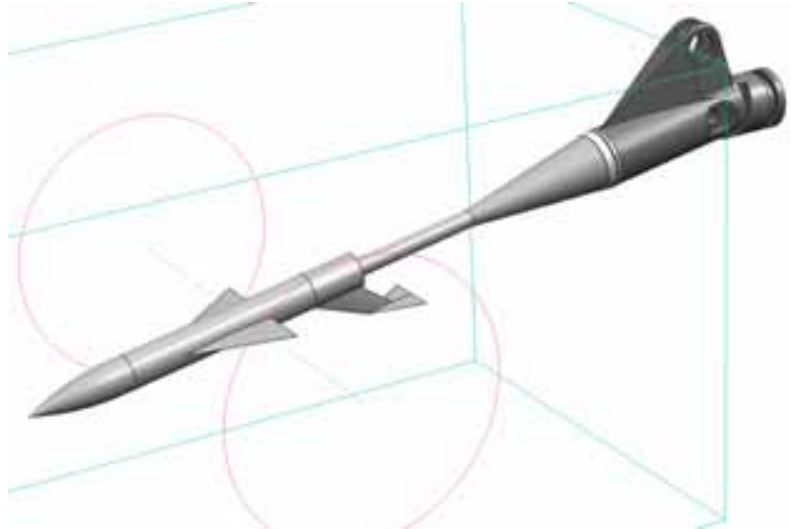

Figure 10. CAD rendering of the $115.8 \mathrm{~mm}$ dia. AGARD-C model, inverted configuration, $\mathrm{T}-38$ test section, $+10^{\circ}$ angle of attack

Analysis of the measured aerodynamic coefficients from the point of test section symmetry were done for two Mach 0.7 runs at the two opposite roll angles: $0^{\circ}$ (model-upright), Fig.9, and $180^{\circ}$ (model-inverted), Fig. 10.

Mach 0.7 data in wind axes system at the aerodynamically same angles of attack from model-upright and model-inverted runs were compared. CAD renderings of the $115.8 \mathrm{~mm}$ dia. AGARD-C model in the both upright and inverted configurations in the T-38 test section, given in Figures 9 and 10, present aerodynamically the same $+10^{\circ}$ angle of attack in the wind axes system.

Comparison of the test data obtained in these two runs showed that there was no noticeable effect on the lift and the drag aerodynamic coefficients. It was noticed that the magnitude of differences in the force (drag and lift, Figures 11 and 12) and pressure measurements (Fig.13), that can be attributed to asymmetry of the test section, are comparable to the total measurement uncertainties [1] confirming a good symmetry of the test section. It should be noted that the test section was calibrated and that the determined flow angularities in vertical and horizontal planes were up-to-date.

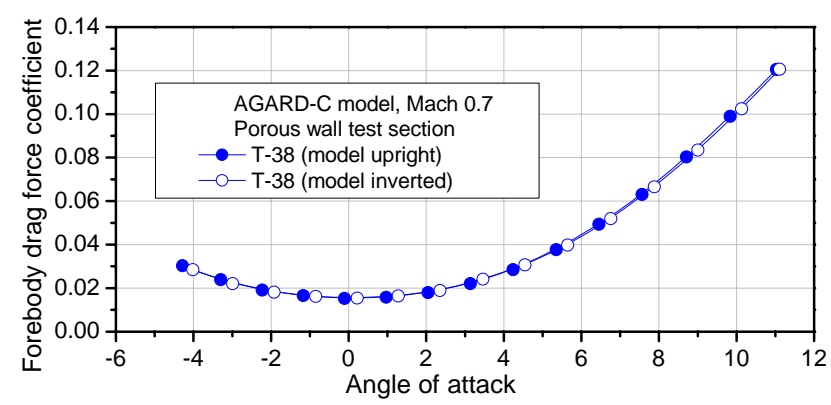

Figure 11. Correlations from the point of test section symmetry in the drag force measurement

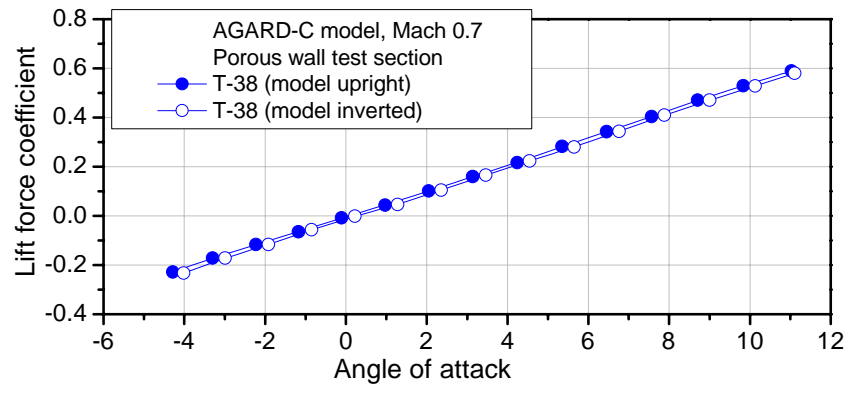

Figure 12. Correlations from the point of test section symmetry in the lift force measurement

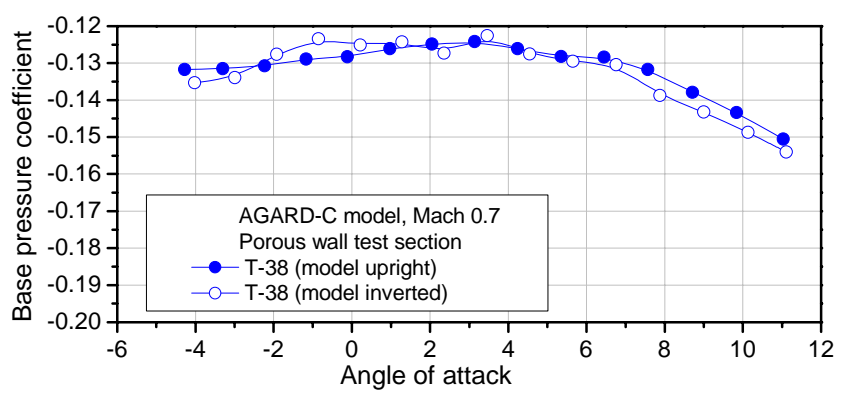

Figure 13. Correlation from the point of test section symmetry in the base pressure measurement

Contrary to the drag coefficient data and lift coefficient data, there is some difference between the pitching moment coefficients obtained in the normal and inverted positions (Fig.14). It is known [7] that the existence of the T-tail makes the AGARD-C model very sensitive (more than the model B) to flow curvature in the test section. Indeed, comparable differences were not observed in the tests of the shorter AGARD-B model in VTI. Therefore, the differences in the pitching moment can be attributed to a small amount of flow curvature in the rear part of the transonic test section, possibly caused by the asymmetry of the model support mechanism (Figures 9 and 10). Further investigation of the observed effect is indicated and the feasibility is being considered of eliminating this asymmetry by differential porosity setting of the upper and lower wall of the downstream part of the transonic test section that is located in the model cart of the T38 wind tunnel.

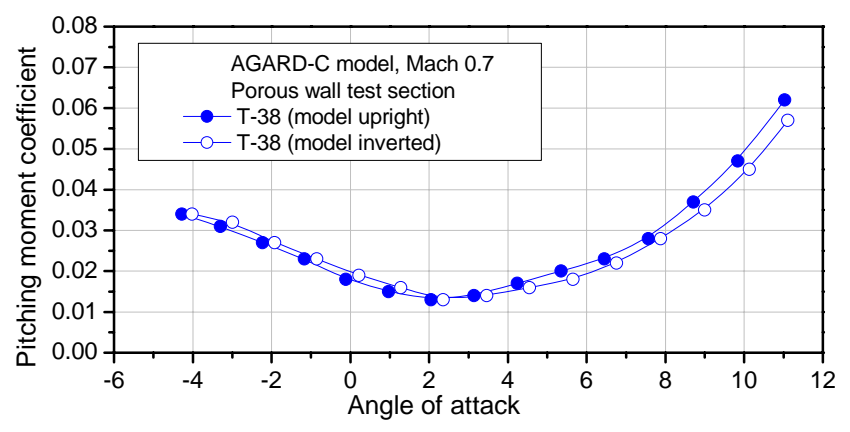

Figure 14. Correlations from the point of test section symmetry in the pitching moment measurement

For comparison, the available data on the differences in pitching moment coefficient for the normal and inverted model position in the NAE/NRC $5 \mathrm{ft}$ wind tunnel are given in Fig. 15. 


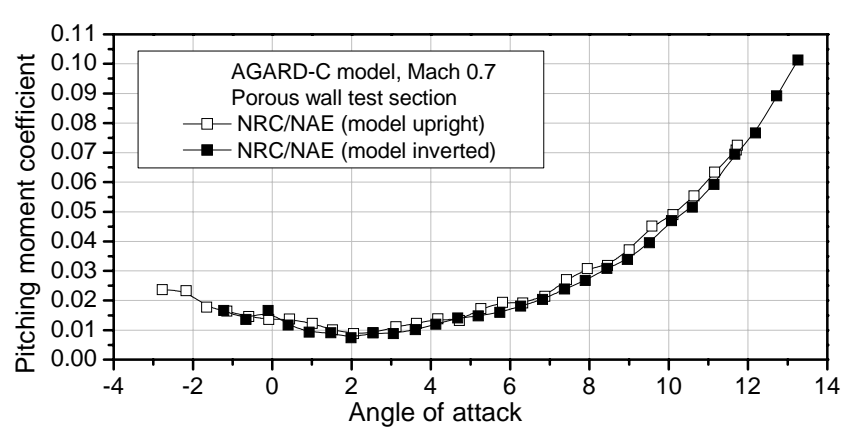

Figure 15. Correlation from the point of test section symmetry in the pitching moment measurement in the Canadian facility

\section{Conclusion}

The intention of the research was to start the statistical control on the standard AGARD-C model test data in accordance with the procedures adopted in VTI and to expand the relatively meager published reference data. There is a need for further tests of this model in order to investigate the preliminary conclusions related to the pitching moment coefficient. Simulations performed by the computational fluid dynamics software tools can be helpful in understanding the observed phenomena.

It will also be of interest to correlate the obtained data with those from the large subsonic wind tunnel of VTI, where the standard model $\mathrm{C}$ has also recently been tested following the adopted procedure. Therefore, the future tests of the AGARD$\mathrm{C}$ model in the T-38 wind tunnel should encompass a wider span of Mach numbers, not only in the transonic range, but in the subsonic range as well. It is expected that, after the introduction of a new T-38 wind tunnel control system and fine tuning of all the wind tunnel systems and subsystems, a new set of data will be referential for future correlations and verifications.

\section{References}

[1] DAMLJANOVIC,D., ISAKOVIC,J., RAŠUO,B.: " $T$-38 Wind-Tunnel Data Quality Assurance Based on Testing of a Standard Model", Journal of Aircraft, 2013, 50 (4), pp.1141-1149.

[2] Recommended Practice: Calibration of Subsonic and Transonic Wind Tunnels, AIAA-R093-2003, AIAA.

[3] REED,T.D., POPE,T.C., COOKSEY,J.M.: Calibration of Transonic and Supersonic Wind Tunnels, NASA Contractor Report 2920, Vought Corporation, 1977.

[4] HEMSCH,M., GRUBB,J., KRIEGER,W., CLER,D.: "Langley Wind Tunnel Data Quality Assurance: Check Standard Results", AIAA 2000-2201, Proceedings of the 21st AIAA Advanced Measurement Technology and Ground Testing Conference, 2000.

[5] Specification for AGARD Wind Tunnel Calibration Models, AGARD memorandum, AGARD, 1955.

[6] Wind Tunnel Calibration Models, AGARD Specification 2, AGARD, 1958.

[7] HILLS,R. (ed.): A Review of Measurements on AGARD Calibration Models, AGARDograph 64, Aircraft Research Association Bedford, England, 1961

[8] Report on Tests Conducted on NACA 0012, and AGARD-B and C Models in the NAE $5 \mathrm{ft}$ Blowdown Wind Tunnel During Training of VTI Personnel: Nov-Dec 1981, DSMA Rept. No. 4001/R84, 1983.

[9] NRC-CNRC Information; Aerodynamics: $1.5 m \times 1.5 m$ Trisonic Blowdown Wind Tunnel, IAR-AL03e National Research Council Canada, 2005.

[10] MUNTEANU,F.: "INCAS Trisonic Wind Tunnel", INCAS-Bulletin, No.1/2009, INCAS National Institute for Aerospace Research Romania, 2009.

[11] The calibration of the transonic and supersonic test section using the $A G A R D$ model $B$ and $C$, Report: RL-ST-14, National Institute for Scientific and Technical Creation, Bucharest, Romania, 1979.

[12] ISAKOVIC,J., ZRNIC,N., JANJIKOPANJI,G.: "Testing of the AGARD B/C, ONERA and SDM Calibration Models in the T-38 $1.5 \mathrm{~m}$ $\times 1.5 m$ Trisonic Wind Tunnel", Proceedings of the 19th ICAS congress, 1994, pp.1-9.

[13] ELfSTROM,G.M, MEDVED,B.: "The Yugoslav 1.5m Trisonic Blowdown Wind Tunnel", Paper 86-0746-CP, AIAA, 1986.

[14] DAMLJANOVIC,D., VITIC,A, VUKOVIC,Đ., ISAKOVIC,J.: "Testing of AGARD-B calibration model in the T-38 Trisonic Wind Tunnel", Scientific Technical Review, ISSN 1820-0206, 2006, Vol.56, No.2, pp.52-62.

\title{
Zapažanja o nekim rezultatima transoničnih aerotunelskih ispitivanja standardnog modela sa T-repom
}

\begin{abstract}
Kao deo periodične provere ispravnosti rada aerotunela, merne instrumentacije i kvaliteta strujanja, serija testova kalibracionog modela AGARD-C je izvršena u trisoničnom aerotunelu T-38 dimenzije $1.5 \mathrm{~m}$ Vojnotehničkog instituta (VTI) u Beogradu. Testovi su obuhvatali merenja aerodinamičkih sila i momenta u transoničnom području Mahovih brojeva u cilju poređenja aerodinamičkih karakteristika modela sa rezultatima iz drugih aerotunelskih laboratorija u skladu sa usvojenom procedurom ispitivanja standardnih modela. Prikazane međulaboratorijske korelacije su bazirane na rezultatima ispitivanja fizički istog modela izvršenih u trisoničnom aerotunelu dimenzije $1.5 \mathrm{~m}$ Nacionalnog istraživačkog saveta Kanade (ranije operativan kao Nacionalna vazduhoplovna ustanova), trisoničnom aerotunelu dimenzije $1.2 \mathrm{~m}$ Nacionalnog instituta za naučno i tehničko stvaralaštvo Rumunije i aerotunelu T-38 tokom primopredajnog perioda. Analiza koreliranih rezultata je potvrdila dobar kvalitet struje u radnom delu aerotunela T-38, dobro stanje aerotunelske strukture i instrumentacije, i ispravnost algoritma za obradu podataka. Primećene su male razlike u rezultatima merenja koeficijenta momenta propinjanja u normalnim i invertovanim položajima modela i preliminarno je zaključeno da su možda izazvane blagom asimetrijom struje u zadnjem delu radnog dela aerotunela jer je poznato da model AGARD-C karakteriše moment propinjanja vrlo osetljiv na lokalne uslove.
\end{abstract}

Ključne reči: aerodinamički tunel, transsonično strujanje, aerodinamički model, aerodinamičke karakteristike, aerodinamičke sile, aerodinamički moment. 


\title{
Наблюдения о некоторых результатах трансзвуковых испытаний в аэродинамической трубе стандартной модели с Т-хвостом
}

\begin{abstract}
В рамках периодического мониторинга работоспособности конструкции аэродинамической трубы, измерительных приборов и качества потока была проведена серия испытаний калибровочной модели АГАРД-Ц в трёхтрубной аэродинамической трубе Т-38 размера 1,5 м Военно-технического института (ВТИ) в Белграде. Испытания включали в себ̆я измерения аэродинамических сил и моментов в диапазоне трансзвуковых чисел Маха с целью сравнения полученных аэродинамических характеристик модели с результатами из других аэродинамических лабораторий в соответствии с принятой процедурой тестирования стандартных моделей. Межлабораторные корреляции были основаны на результатах испытаний физически одной и той же модели в трёхтрубной аэродинамической трубе длиной 1,5 м Национального исследовательского совета Канады (позднее работавшего в качестве Национального авиационного учреждения), в трёхтрубной аэродинамической трубе длиной 1,2 м румынского Национального института для научных и технических исследований, и в аэродинамической трубе Т-38 в период ввода в эксплуатацию. Анализ результатов испытаний корреляции подтвердил хорошее качество потока в испытательной секции аэродинамической трубы T-38, хорошее состояние конструкции аэродинамической трубы и измерительных приборов, а также правильность алгоритма для сокращения данных. Небольшие различия наблюдались в данных коэффициента момента тангажа, полученных в «нормальных» и «перевёрнутых» конфигурациях модели, и было предварительно сделано заключение, что эффект может быть вызван небольшой асимметрией потока в задней части аэродинамической трубы. Модель АГАРД-Ц известна высокой чувствительностью момента тангажа к местным условиям.
\end{abstract}

Ключевые слова: аэродинамическая труба, трансзвуковой поток, аэродинамическая модель, аэродинамические характеристики, аэродинамические силы, аэродинамический момент.

\section{Observations sur quelques résultats des essais dans le tunnel transsonique du modèle standard avec $T$ - queue}

\begin{abstract}
Comme la part du contrôle périodique du fonctionnement du tunnel, des instruments de mesurage et de la qualité du courant on a effectué une série de tests pour le modèle de calibrage AGARD-C dans le tunnel trisonique T-38 de 1,5m à l'Institut militaire technique (VTI) à Belgrade. Ces tests ont compris le mesurage des forces aérodynamiques et des moments dans la portée transsonique des nombres de Mach dans le but de comparer les caractéristiques aérodynamiques du modèle avec les résultats obtenus dans d'autres laboratoires des tunnels aérodynamiques selon la procédure adoptée pour les essais des modèles standards. Les corrélations présentées entre les modèles se basent sur les résultats des tests faits sur le modèle physiquement le même dans le tunnel trisonique de 1,5m au Conseil national des recherches du Canada (opératif avant comme Etablissement national d'aviation), dans le tunnel trisonique de 1,2m de l'Institut national pour la création scientifique et technique de Roumanie et dans le tunnel aérodynamique T-38 pendant le transfert. L'analyse des résultats corrélatifs a confirmé bon qualité du courant dans la partie de travail du tunnel aérodynamique T-38, bon état de la structure de tunnel et des instruments ainsi que l'exactitude de l'algorithme pour le traitement des données. Les petites différences ont été observées chez les résultats de mesurages des coefficients du moment de tangage dans les positions normales et inverties du modèle et on a conclu qu'elles ont été provoquées peut-être par l'asymétrie légère du courant dans la partie postérieure de région de travail du tunnel aérodynamique. Il est connu que le modèle AGARD se caractérise par le moment de tangage très sensible aux conditions locales.
\end{abstract}

Mots clés: tunnel aérodynamique, courant transsonique, modèle aérodynamique, caractéristiques aérodynamiques, forces aérodynamiques, moment aérodynamique. 